\title{
MANAGEMENT AND CONTROL OF SPORTS PREPARATION OF 14-15-YEAR-OLD FEMALE BASKETBALL PLAYERS
}

\author{
Mariana Borukova \\ National Sports Academy “Vassil Levski”, Sofia, Bulgaria
}

\begin{abstract}
Knowing the age and gender characteristics of children is a prerequisite for the sports pedagogue to manage the different stages of the multi-annual sports training. The complex development of motor skills raises the question of the assessment and control of the specific functional training of the athletes. Permanent control over the level of development of basic motor skills allows coaches to determine the main directions for optimization of the educational and training process and to work more effectively for the development of specific technical and tactical skills of adolescent basketball players. Undoubtedly, one of the main factors of gaming efficiency is the ability of the athletes to materialize their motor potential in rational technical and tactical actions. To the greatest extent, the contribution of each of the indicators studied to the sports performance of an individual or group depends on 3-4 key factors.

The disclosure of the factor structure of physical development and the specific work capacity of 14-15-year-old basketball players is of high information value for the optimization of the training process. In the present study, the five identified factors have the largest contribution to the basketball achievement for this age group.
\end{abstract}

Key words: basketball, growing up basketball players, optimization, educational and training pro cess

\section{INTRODUCTION}

Modern basketball is extremely spectacular and attractive sport which poses a lot of requirements to elite basketball players. A complex development of motor abilities is needed as well as speed-power abilities combined with virtuosic technique. All these add beauty and magic to this game and make it a favorite sport for a lot of people.

Unfortunately, in the last few years there has been a recession in the development of women's basketball both on national and international level. We consider that part of the reasons for this state is the bad selection of female players, the difficulty in keeping them in the sports hall once they turn 17 years old, insufficiently effective education-training work with adolescents, and the small number of competitions.

Prior to sports-competitive season
2017/2018 the Bulgarian Basketball Federation banned any foreign competitors from participating in the Bulgarian tournament. The sports clubs with female players had to pay much greater attention to their work in the basketball schools for young players, as well as to depend mainly on the realization of their own competitors.

The term "young players" includes all youngsters actively engaged in training sessions under the guidance of a sports pedagogue; this is the age group between minibasketball and 18-year-old basketball players (Aleksieva, 2010).

\section{Nature and specific peculiarities of the} selection process in basketball

Modern basketball is incomparable with the play of the first periods of its development. The increasing dynamics poses new, higher and specific requirements to its par- 
ticipants (Tzarov, 2008). One of the peculiarities of education and training over years was their dependence on the play list of the team (Zhelyazkov, 1978, Karalejič, Jakovljevič, 2007). The major problem in this direction is the structural building of the teams. Being a constant factor for the play and competitive efficiency, it is closely related to the selection and initial sports preparation of players with favorable morph functional and psychomotor qualities for the different positions in play. In this sense, one of the main tasks of the selection is detecting, evaluating and training capable players (Tzarov, Djordjevich, 1997, Tzarov, 2001).

The issue of the structural building of the teams enhances the interest towards research related to the selection of prospective basketball players (Ackland, Schreidner, Kerr, 1997,Dimitrova, 2004, Karalejič, Jakovljevič, 2001, Tzarov, Djordjevich, 1997, Tzarov, 2001).

The parity between the indexes for structural building of the teams directs specialists' attention to new reserves for increasing the play and competitive efficiency of players and teams (Tzarov, Djordjevich, 1997). Reaching the peaks in sports performance is impossible without the mutual efforts of a number of sports specialists, medical personnel, psychologists, etc. They have to detect the sports talents and carefully "raise" them throughout the years. Iancheva (Iancheva, 2009) did research aimed at revealing the psychological dimensions of sports talent. Together with other psychic qualities determining the psychological profile of the successful athlete, the author emphasized on high sports confidence, the positive expectations of one's own efficiency, as well as the low level of self-perception.

Success in the development of young basketball players is related mostly to their coaches. They have the leading role in this process. The more knowledge and qualifications they have, the bigger the success, the steadier the development, and the more prospective future their players will have.

When selecting young players, one has to predict the existence of "individual peculiarities developing during puberty period". About $15-20 \%$ of them are accelerants and they go into puberty one, two or more years earlier; $10-15 \%$ of them are retardants, i.e. go into puberty a year or two later. The rest $65-70 \%$ are with normal development - the so-called medians (Tzarov, 2008).

A good option is that the selection be made on the base of coordinated actions of the clubs and medical centers which will examine each child's motor abilities.

\section{Systems of control and evaluation of sports preparation in basketball}

Knowing children's age and gender peculiarities is a premise for the sports pedagogue to manage the different stages of athletes' sports preparation of many years. The development of their motor qualities complies with their sensitive periods.

The permanent control over the level of development of basic motor qualities allows coaches to set the main directions for optimization of the education-training process and to work more efficiently towards development of specific technical-tactical skills of young basketball players (Tzarov, 2008). This could not be done without the necessary motivation on behalf both of players and of their coaches. The term "motivation" is defined as "hypothetical, suggested structure, used to characterize inner and outer powers which lead to enterprise, purposefulness, intensity and stability of behavior". The newest data reveal the multi-direction influence of motivation on coping strategies in stress situations, coach's leadership style, competitive interaction and overall behavior (Domuschieva, 2001).

The complex development of motor qualities poses the question of the evaluation and control over the specific functional preparation of the players. For this purpose, a lot of 
researchers have developed specific basketball tests and indexes (Zhelyazkov, 1978, 1998, Zhelyazkov, Köle, 1993, Dasheva, 1991). A substantial contribution in this direction was made with the introduction of pulsometry, the control over $\mathrm{La}, \mathrm{BE}, \mathrm{VO}_{2 \max }$, and other biochemical and physiological indexes.

We found a great variety of test batteries with combinations of different tests in basketball literature.

One of the most recent and commonly used test batteries in Serbia was developed by basketball specialists. It includes 10 tests for specific basketball abilities and skills (Karalejič, Jakovljevič, 2007), parts of which have been used for control and evaluation of the best Bulgarian basketball players (Tzarov, Tzarova 2007).

Tz. Jeliazkov, Y. Brogli, P. Nojarov (1984) developed "a system of control and evaluation of the effect from preparation of the sports reserve". They proposed several tests which measured the different motor qualities of young basketball players.

In basketball practice it is necessary to evaluate the degree of preparation of the young players on a regular basis. This helps coaches to obtain the necessary information which could be used as a guideline about the level of their development - whether they possess the necessary physical qualities and basketball skills, whether they make any progress in the education-training process, and whether they will develop as highly qualified athletes in the future (Karalejič, Jakovljevič, 2001).

Transverse research related to age was done among young basketball players by $\mathrm{R}$. Tzarova (1981). The author reveals the peculiarities of play efficacy and specific efficiency with boys and girls from the main age groups (13-15-year-old, 16-17-year-old and 18-19-year-old) and developed tests for control, evaluation and optimization of play efficacy and specific efficiency of each of them.

With permission by the Bulgarian Basket- ball Federation from 1979, the teams of "A" group (men and women) implemented "system of control, evaluation and optimization of sports preparation", developed by prof. Tzvetan Zeliazkov et al. This system comprises the main factors of sports achievement - object of management in the process of sports preparation. With its help, on the base of objective criteria, the permanent control and evaluation of the best (elite) basketball players in Bulgaria was made possible (Tzarova, 1981).

There are three systems of control, evaluation and optimization of sports preparation for the young players (Giosheva, Tzarov, Tzarova, 1990).

The analysis of the above-mentioned facts, our personal experience, and our observations allow us to formulate the following work hypothesis: we assume that the present research will allow for outlining and identifying the major 4-5 factors with the greatest contribution to sports achievement in basketball. Revealing the factor structure of the physical development and specific efficiency with 14-15-year-old basketball players is of high informative value for the optimization of the education-training process.

\section{METHODOLOGY}

The research was done in the period March 2015 - December 2016.

The aim of the research is to increase the preparation of young basketball players (14-15-year-old girls) through development of a system for control, evaluation and optimization of the major factors of sports achievement.

In the process of the research we made a complex survey to establish the level of physical development, motor preparation and play efficiency with 14-15-year-old basketball players, involved in an organized educationtraining process. 


\section{Main tasks:}

1. To establish the level of physical development and specific efficiency of the researched age group.

2. To reveal the degree and nature of dependence between the tests for physical development and specific efficiency.

3 . To outline and identify the major factors of physical development and specific efficiency with the girls from the researched age group.

Object of research is sports preparation of young female basketball players.

Subject of research is the indications of physical development and sports preparation of 14-15-year-old female basketball players

Contingent of the research is 66 female basketball players born in 2001-2003from the first five clubs with best achievements in the National Tournament of Bulgarian Basketball Federation in the season 2014/2015.

To fulfill the aim and tasks of the research, we applied the following research methods:

1. Survey and theoretical analysis of the specialized literature and document sources - to find out about the researched issue. On this base we selected several tests and indexes, meeting the requirements for reliability, authenticity, objectiveness and standardization, and included them in the test battery of the research.

2. Anthropometrics - to reveal the state of the main anthropometric indicators through collecting information along 5 indexes (see table 2). The measurements were made with standard tools and standard methods (Slanchev, 1998).

3. Sports-pedagogical testing - to establish the level of specific physical preparation and specific technical-tactical skills of the researched basketball players. The 15 tests used are presented in table 1 (from № 6 to № 20).

Depending on the information they provide, the indexes were divided into groups, as follows:
- For special physical preparation -8 indexes (from $6^{\text {th }}$ to $13^{\text {th }}$ );

- For special technical-tactical preparation -7 indexes (from $14^{\text {th }}$ to $20^{\text {th }}$ ).

Math-statistical models for assessment of the results from the research

The results from the research were analyzed statistically with:

1. Variation analysis - to determine the mean levels of the variance of the researched indexes with each of the surveyed samples.

2. Factor analysis -to reveal the factor structure of the physical development and specific efficiency. The initial correlation matrixes were factorized with the method of main components, followed by Varimax orthogonal rotation (Wainer/Braun, 1988). The making of the inter correlation matrixes and deriving the factors was done through the so-called R-technique, where a certain number of units of the observation $-\mathrm{n}$ (in this case - the researched girls) is evaluated with a defined number of indexes $-m$. This option supposes the condition $n>m$. Only the factors with a load of more than $1(\mathrm{E} \geq 1)$ - criterion of Kaizer are commented (Gigova, 2002, Tzarova, 2013).

\section{Method of indexes - (Body Mass Index} - BMI) - recommended by the World Health Organization for establishing the degree of stoutness of the body.

To evaluate the Body Mass Indexes of the researched pupils, we used the adapted table of P. Slanchev (1992) for diagnosis of obesity in young age.

\section{RESULTS}

The results from the variation analysis of the observed indexes of physical development and the physical and technical-tactical preparation are displayed in table 1.

The factor structure with 14-year-old basketball players consists of 5 main factors ( $t a-$ ble 2) which explain a very high percentage of the initial dispersion of the examined phenomenon $(84.24 \%)$. 
Table 1. Mean values and variance of the examined indexes

\begin{tabular}{|c|c|c|c|c|c|c|c|c|}
\hline Indicators & $\mathbf{N}$ & .Min & .Max & $\mathbf{X}$ & $\mathbf{S}$ & As & $\mathbf{E x}$ & $\mathbf{V}$ \\
\hline 1. Height & 66 & 145,00 & 179,00 & 164,87 & 7,75 & $-0,325$ & $-0,512$ & 4,70 \\
\hline 2. Weight & 66 & 36,00 & 79,00 & 56,48 & 10,12 & $-0,062$ & $-0,652$ & 17,93 \\
\hline 3. Body mass index & 66 & 13,78 & 29,12 & 20,65 & 3,01 & 0,222 & $-0,230$ & 14,59 \\
\hline 4. Lower limb & 66 & 88,00 & 113,00 & 100,07 & 6,13 & 0,159 & $-0,656$ & 6,12 \\
\hline 5. Upper limb & 66 & 65,00 & 82,00 & 74,05 & 4,41 & $-0,157$ & $-1,145$ & 5,96 \\
\hline 6. Span length & 66 & 17,50 & 24,00 & 21,02 & 1,37 & $-0,460$ & 0,241 & 6,50 \\
\hline 7. Chest measurement-pause & 66 & 66,00 & 95,00 & 81,35 & 7,84 & 0,007 & $-0,963$ & 9,63 \\
\hline $\begin{array}{l}\text { 8. Chest measur. - respir. } \\
\text { difference }\end{array}$ & 66 & 4,00 & 12,00 & 7,78 & 1,71 & $-0,189$ & 0,193 & 22,04 \\
\hline 9. Horizontal stretch & 66 & 140,00 & 180,00 & 164,91 & 9,15 & $-0,561$ & $-0,127$ & 5,55 \\
\hline 10. $\mathrm{m}$ sprint 20 & 66 & 3,16 & 4,22 & 3,75 & 0,24 & $-0,307$ & 0,313 & 6,40 \\
\hline 11. Running between stands & 66 & 20,02 & 26,40 & 22,49 & 1,39 & 0,693 & 0,154 & 6,19 \\
\hline 12. Shuttle" run $112 \mathrm{~m} "$ & 66 & 23,13 & 34,21 & 28,65 & 2,10 & 0,033 & 1,120 & 7,34 \\
\hline 13. High jump & 66 & 22,00 & 53,00 & 33,94 & 5,83 & 0,574 & 0,787 & 17,19 \\
\hline 14. Long jump & 66 & 130,00 & 220,00 & 177,12 & 20,46 & $-0,156$ & $-0,419$ & 11,55 \\
\hline 15. Throwing compact ball & 66 & 2,90 & 5,30 & 4,15 & 0,58 & 0,059 & $-0,629$ & 13,88 \\
\hline 16. Moving in defense & 66 & 8,44 & 12,36 & 10,72 & 0,79 & $-0,306$ & 0,000 & 7,40 \\
\hline 17. Abdominal press & 66 & 12,00 & 52,00 & 24,15 & 8,41 & 1,375 & 1,630 & 34,83 \\
\hline 18. Dribble between stands & 66 & 20,82 & 30,10 & 24,03 & 1,96 & 1,234 & 1,930 & 8,18 \\
\hline 19. Leading the ball index & 66 & $-1,72$ & 7,29 & 1,54 & 1,20 & 1,885 & 8,290 & 77,73 \\
\hline 20. Loops made by dribble & 66 & 8,00 & 88,00 & 44,61 & 14,99 & $-0,213$ & 0,828 & 33,60 \\
\hline $\begin{array}{l}\text { 21. Shooting while moving - } \\
\text { time }\end{array}$ & 66 & 32,54 & 45,77 & 36,42 & 2,16 & 1,338 & 4,376 & 5,94 \\
\hline $\begin{array}{l}\text { 22. Shooting while moving - } \\
\text { number }\end{array}$ & 66 & 4,00 & 6,00 & 5,27 & 0,69 & $-0,421$ & $-0,833$ & 13,12 \\
\hline $\begin{array}{l}\text { 23. Shooting while moving - } \\
\text { coeffic. }\end{array}$ & 66 & 5,42 & 11,44 & 7,04 & 1,21 & 1,286 & 2,024 & 17,14 \\
\hline 24. Shooting from place & 66 & 7,00 & 25,00 & 16,91 & 3,41 & $-0,625$ & 1,220 & 20,16 \\
\hline 25. Free throws & 66 & 8,00 & 19,00 & 12,94 & 2,58 & $-0,153$ & $-0,703$ & 19,92 \\
\hline
\end{tabular}


Table 2. Factor structure of physical development and physical efficiency with 14-year-old basketball players

\begin{tabular}{|c|c|c|c|c|c|c|c|c|}
\hline № & Indicators & $\mathbf{I}$ & II & III & IV & $\mathbf{v}$ & $\mathbf{h}^{2}$ & $1-h^{2}$ \\
\hline 1. & Height & ,906 & , 109 & 081 &, 123 &,- 046 &, 856 &, 144 \\
\hline 9. & Weight & ,902 & 085 & ,147 & ,145 &,- 106 &, 874 & , 126 \\
\hline 15. & Body mass index & ,901 &,- 158 &, 07 &, 037 &, 035 &, 845 &, 155 \\
\hline 4. & Lower limb & 877 & 095 & ,296 & ,101 &,- 019 &, 779 & ,221 \\
\hline 5. & Upper limb & 803 & ,269 & ,135 & ,176 &, 113 &, 876 &, 124 \\
\hline 2. & Span length & ,788 & ,453 & 085 &,- 285 &,- 065 & ,918 & 082 \\
\hline 7. & Chest measurement - pause & ,762 & ,367 &,- 059 &,- 168 &, 111 &, 759 & ,241 \\
\hline 6. & Chest measur. - respir. difference & ,601 &,- 024 &, 032 & ,325 &, 017 &, 469 &, 531 \\
\hline 3. & Horizontal stretch &, 524 & ,472 &,- 024 &,- 476 &,- 066 & ,729 & ,271 \\
\hline 21. & $20 \mathrm{~m}$ sprint &,- 123 & ,715 & ,249 &, 082 &,- 253 & 658 & ,342 \\
\hline 13. & Running between stands & ,247 &,- 713 & ,155 & ,285 &,- 093 & ,683 & ,317 \\
\hline 10. & "Shuttle" run $112 \mathrm{~m}$ &,- 291 & ,685 &,- 128 & 007 & 029 &, 571 & ,429 \\
\hline 23. & High jump &,- 118 & ,632 &,- 318 & ,395 &,- 445 &, 868 &, 132 \\
\hline 16. & Long jump &,- 307 & ,628 &,- 05 & ,297 &, 174 & ,617 &, 383 \\
\hline 15. & Throwing compact ball & 088 &,- 603 &,- 172 &,- 303 &,- 061 &, 845 & ,155 \\
\hline 8. & Moving in defense &, 050 &,- 581 &, 340 &, 028 &,- 143 &, 477 &, 523 \\
\hline 11. & Abdominal press &,- 334 &, 578 &, 560 &,- 054 & 185 & ,797 & ,203 \\
\hline 22. & Dribble between stands & 095 &,- 477 &, 470 &,- 424 & ,406 & ,802 & ,198 \\
\hline 18. & Leading the ball index &,- 312 & ,395 &, 740 & ,127 & ,236 &, 87 & ,134 \\
\hline 17. & Loops made by dribble & ,219 &,- 063 &,- 638 & ,236 & ,232 &, 566 & ,434 \\
\hline 19. & Shooting while moving - time &,- 124 &,- 025 &, 562 & ,264 & ,172 & ,429 &, 571 \\
\hline 24. & Shooting while moving - number &, 157 &, 16 &,- 451 &,- 125 & ,334 &, 381 &, 619 \\
\hline 14. & Shooting while moving -coeffic. &, 18 &,- 456 & 023 &, 594 &,- 156 & ,617 &, 383 \\
\hline & Shooting from place & 087 & 057 &,- 081 &,- 476 &,- 625 &, 628 &, 372 \\
\hline 25. & Free throws & ,247 & , 143 &,- 474 & ,026 & ,558 & ,619 &, 381 \\
\hline
\end{tabular}

Besides factor loads, the table presents data about the size of the explained $\left(\mathrm{h}^{2}\right)$ and unexplained $\left(1-h^{2}\right)$ initial dispersion by each index.

The analysis of table 2 shows that the first outlined factor explains $25.53 \%$ from the initial dispersion of the researched phenomenon.
The two factors, which follow, have a lower contribution to the total physical development and specific efficiency of female basketball players $(18.60 \%$ and $10.95 \%$ respectively); the last factors are complementary and the explained dispersion by them is a way less than $10 \%-(7,43 \%$ and $6,20 \%)$. 


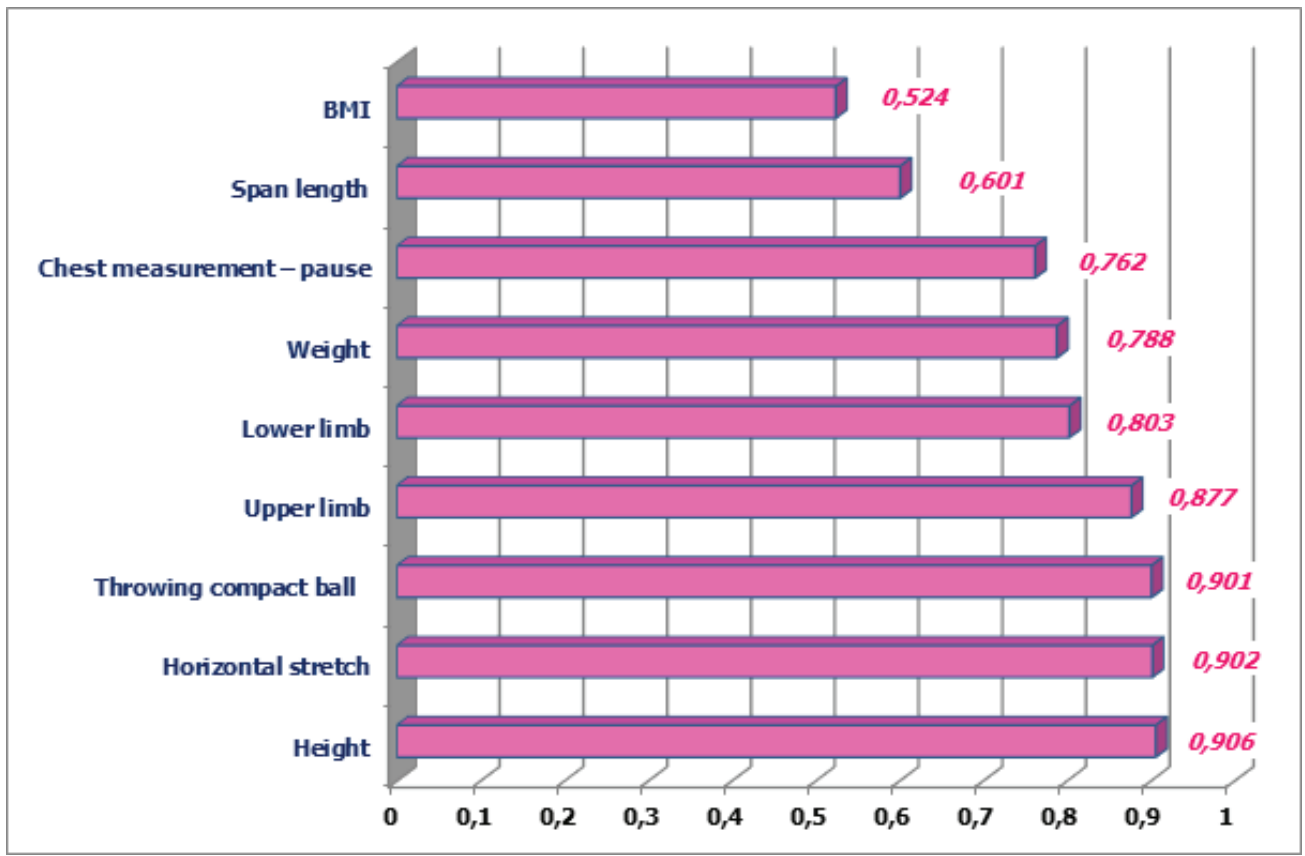

Fig. 1. Factor structure of the physical development of 14-year-old basketball players - I factor (morphological)

The first factor in the factor structure of the tor can be defined as morphological because it physical development and specific efficiency of 14-year-old basketball players (figure 1) is determined by nine main indexes. As we have already pointed out, it explains the highest percentage of the initial dispersion of the reveals the place of the indexes related to the length of the body and height-weight indexes in the factor structure. They, on the other hand, are a premise for higher achievements when researched phenomenon $(25.53 \%)$. This fac-

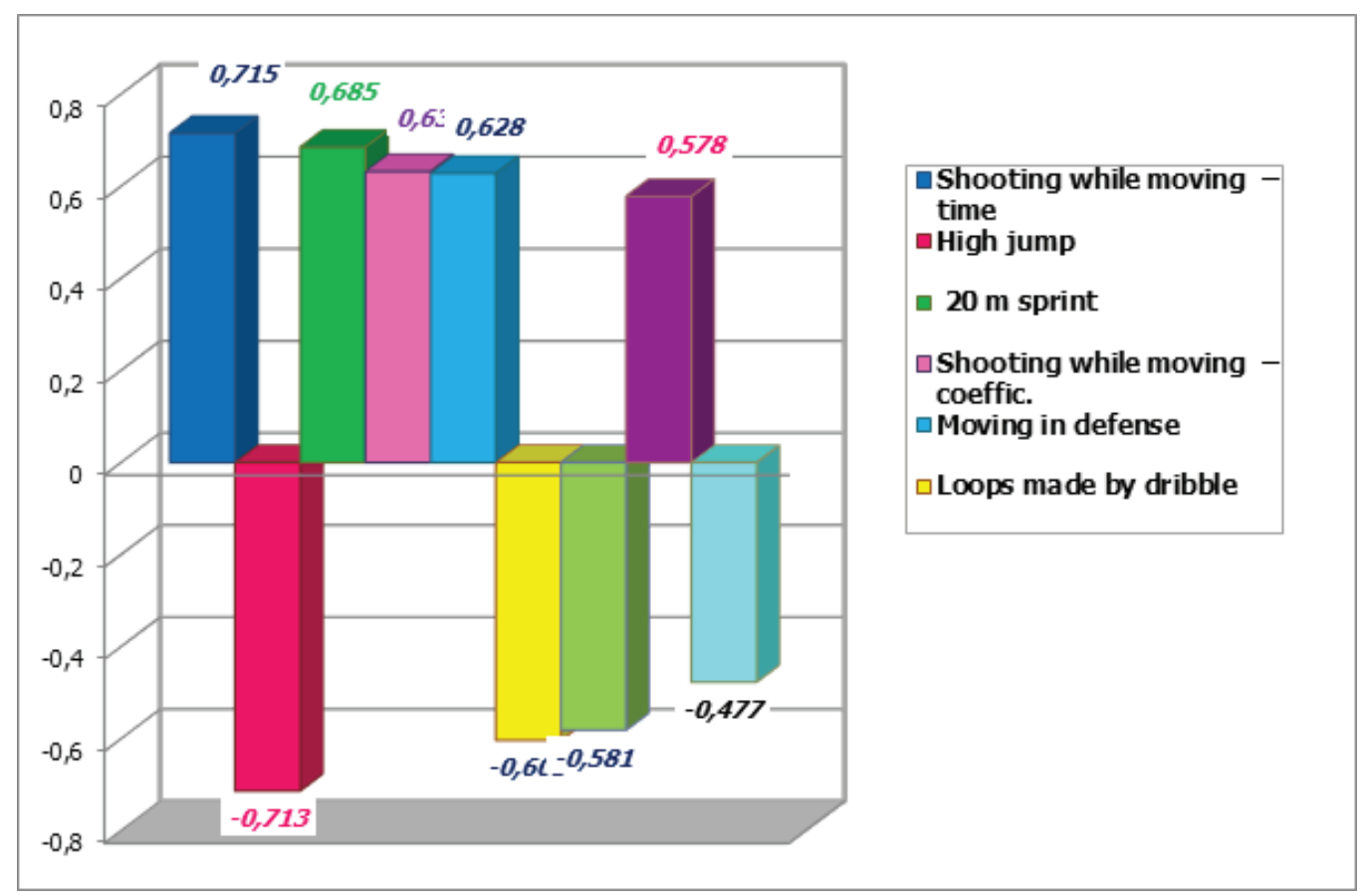

Fig. 2. Factor structure of physical preparation of 14-year-old female basketball players - II factor 
The second factor in the factor structure of the physical development and specific efficiency of 14-year-old female basketball players (fig. 2) is also determined by nine main indexes. They explain a high percentage of the initial dispersion of the researched phenomenon $(18.60 \%)$. The indexes, which determine this factor, are related to physical preparation of the female basketball players. In the researched age groups, the bigger functional capacity of the girls' chest is a premise for higher achievements in moving down the court with or without a ball, in fast movement in guarding position, handling the ball on one spot, as well as making a basket for the shortest time (table 2).

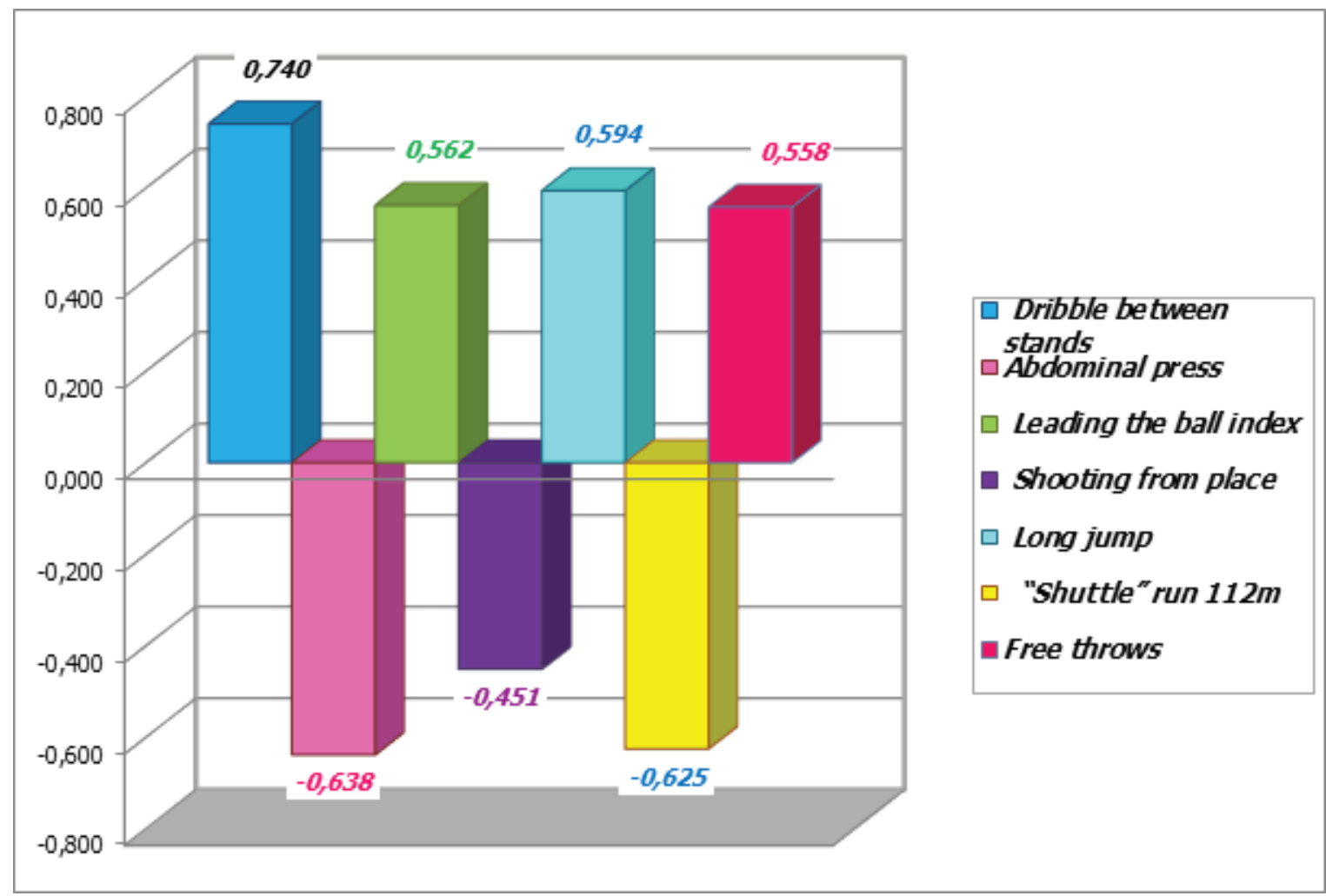

Fig. 3. Factor structure of specific preparation of 14-year-old female basketball players III, IV, $V$ factors

The third factor in the factor structure of the physical development and specific efficiency of 14-year-old female basketball players (fig. 3) is determined by four main indexes, which explain $10.95 \%$ of the initial dispersion of the researched phenomenon. These are the indexes related to basketball skills of the female basketball players; therefore, it can be identified as technical-tactical factor. It reveals the high significance of the dribbling skills, efficiency of shooting after a pass, the dynamics of the abdominal muscles for the overall preparation of the young female basketball players.
The fourth factor (fig.3) is determined by the index related to the explosive power of the lower limbs in horizontal efforts $(7.43 \%)$.

The last fifth factor $(6.97 \%)$ reveals the place of the physical development and specific efficiency (fig. 3) of speed endurance and free shots efficiency in the factor structure.

\section{DISCUSSION}

To fulfill the aim and tasks of the research, we compared the obtained results with the results from a research done in 2011. The comparative analysis of the mean value of each of the researched indexes (a total of 18) of the two 
researched groups showed that the researched group in 2016 has shown better results only along three indexes. These are the indexes related to the dynamics of the abdominal muscles, the shooting skills after a pass, and free shots efficiency. Along all the other 15 indexes the group researched in 2011 has shown better results. The comparison of the two mean values determines only the presence of difference but does not allow us to make general conclusions without applying the criterion of Student, which is not a subject of this study.

The results from the variation analysis of the observed indexes of physical development and physical and technical-tactical preparation of the girls researched in 2016 (table 1) show that the values have a normal distribution. The observed sample is homogeneous and relatively homogeneous as regards the indications explained by these indexes. Lack of homogeneity is observed as regards the female basketball players' skills to handle the ball on one spot, their ability to move down the court while dribbling with high speed, and the dynamics of their abdominal muscles.

The analyses of the results from the research done in 2011 shows the values have a normal distribution. The observed sample is homogeneous and relatively homogeneous as regards the indications explained by these indexes. The only index which is not stable is the female players' ability to move down the court while dribbling with high speed (Tzarov, Tzarova, 2001). We can summarize that the basketball players researched in 2016 have weaker ball handling skills compared to the girls researched in 2011. In our opinion, this is due to the less time and attention sports pedagogues take to deal with specific basketball adroitness skills.

\section{CONCLUSIONS}

The analysis of the results and the general look at the factor structure of physical development and specific efficiency with 14-15-year-old female basketball players researched in 2016 enable us to formulate the following conclusions:

The most important for the 14-year-old female basketball players is the so called morphological factor, which reveals the high significance of the length of the body and height-weight indexes.

Physical preparation and technical-tactical preparation have a smaller contribution to the overall physical and technical-tactical preparation with the 14-year-old female basketball players.

After an analysis of the results of the 14-15-year-old female basketball players researched in 2011, the following conclusions were formulated:

The most important for the female basketball players is the factor explaining their basketball skills, which reveals the high significance of:

Skills related to the movement down the court in attack with high speed, with dribble or without dribble;

Skills for fast movement in defense;

The height of the players influences negatively these skills.

The second factor can be identified as morphological factor, determining the significance of the size of the body in basketball, which, however, has a negative influence on speed abilities of the researched players (Tzarov, Tzarova, 2001).

The analysis of the integral factor structure of physical development and specific efficiency of the 14-15-year-old female basketball players who took part in the two surveys (in 2011 and 2016) shows that with both groups there are five main factors which explain a high percentage of the initial dispersion - respectively $79.87 \%$ for the group in 2011 , and $84.24 \%$ for the group in 2016 . This percentage could be higher if the number of the factors is increased, but thus, the significance of the information would not rise. 
We could summarize that the selection of the players researched in 2016 was weaker. Besides, they need to take more time working with the ball, or the so-called basketball adroitness, which are unfortunately mastered in the opening period of sports training and are only perfected on this stage.

In one of the recent surveys (Tzarova, Borukova, 2011) made in the period 20122015 among 12-19-year-old female basketball players, the authors found out that nowadays athletes have much lower results compared to the older generations. The trend is that the results will decrease every year in the future (Tzarova, Borukova, 2011). The age of 14-15 is crucial for the development of the young girls as basketball competitors. They are in a period of sports development and it is important that the work during the education-training process be directed towards development and perfection both of the individual qualities as group actions, team interactions and play efficiency (in attack and defense). The analysis of the results of the present study will allow us to develop tests for evaluation of physical development and motor preparation of the 14-15-year-old female Bulgarian basketball players. This will help the improvement of the education-training process and competitive process and will increase the efficiency of the exerted control.

\section{REFERENCES}

Ackland, T., Schreidner, A., Kerr, D. (1997). Anthropometric normative data for female international basketball players', The Australian Journal of Science and Medicine in Sport. 29. 1.

Aleksieva, M., (2010), Varianti za optimizirane iziavite na podrastvashti igrachi po basketball (studia), Pedagogicheski almanah, Universitetsko izdatelstvo "Sv. Sv. Kiril I Metodii" // Варианти за оптимизиране изявите на подрастващи играчи по баскетбол. (студия) Педагогически алманах, Университетско издателство „,Св. св. Кирил и Методий”

American Alliance for Health, Physical Education, Recreation and Dance (AAHPERD), (1984). Basketball for boys and girls: skill test manual VA: Reston.

Borukova, M., „Factor structure and basic factors of the physical development and the specific workability of growing up basketball players (12-19 years old)"- Proceeding book of FIEP International Scientific Congress of Physical Education and Sport-Competences for life, 9-12 October 2014, p.287-296.

Borukova, M., (2014). Improve the system for reception and control of basketball talent in the system of sports schools in Bulgaria, Dissertation, NSA "Vassil Levski”, Sofia, p. 69-77 // Усъвършенстване на системата за прием и контрол на баскетболни таланти в системата на спортните училища в България Дис. труд, НСА. София., стр. 69 -77 .

Borukova, M., Nedyalka Mavrudieva, Brestnichki Georgi, Tzarova Asia, (2016), Analysis and evaluation of sports preparation of youth female basketball athletes, Proceeding book of $1^{\text {st }}$ Afro-European Congress of FIEP, E.N.D.s.r.o. Topol'čianky, Slovakia

Borukova, M. (2017) Factor structure and basic factors of the physical development and the specific workability of growing up girl basketball players (14 years old), RIK, vol. 45, issue 1, p. 17-20, Federation of the Sports Pedagogues of the Republic of Macedonia.

Borukova, M., D. Dasheva, (2017), History of Bulgarian basketball, History of European basketball, FIEP, Nis - Leposatovic

Borukova, M., Tz. Tzankov (2016) Uchebni programi za obuchenie po sportna podgotovka $\mathrm{v}$ sportnite uchilishta. Rakovodstvo, Sofia//,Учебни програми за обучение по спортна подготовка в спортните училища". Ръководство, София.

Dasheva, D., (1991). Stress I stresovi vazdeistvia $\mathrm{v}$ podgotovkata na basketbolisti, Dissertation, VIF, Sofia // Стрес и 
стресови въздействия в подготовката на баскетболисти, Дис. Труд. ВИФ. София.

Zhelyazkov, Tz. (1978), Metodologichni osnovi na upravlenieto I optimiziraneto na sportnata podgotovka pri visokokvalificirani basketbolisti. Dissertation for DSc, Sofia, VIF // Методологични основи на управлението и оптимизирането на спортната подготовка при висококвалифицирани баскетболисти Дисерт. труд - дпн, София, ВИФ.

Zhelyazkov, Tz., Köle,V., (1993). Izsledvane na specifichnoto funkcionalno natovarvane pri visoko kvalificirani basketbolisti, Sport I nauka, vol.7, p.5-9 // Изследване на специфичното функционално натоварване при високо квалифицирани баскетболисти,Спорт и наука, брой.7, с. 5-9.

Zhelyazkov, Tz (1998). Основи на спортната тренировка. НСА-Печатна база. София. // Osnovi na sportnata trenirov$k a$, NSA Press, Sofia

Zhelyazkov, Tz, D. Dasheva (2006). Основи на спортната тренировка. София: Гера арт.// Osnovi na sportnata trenirovka, Sofia, Gera art.

Zhelyazkov, Tz, D. Dasheva (2011). Основи на спортната тренировка. София. // Osnovi na sportnata trenirovka, Sofia.

Zhelyazkov, Tz, Broglie, J., Nojarov, P. (1984). Система за контрол и оценка на ефекта от подготовката на спортния резерв. София. // Sistema za control na ocenkata na efekta ot podgotovkata na sportnia rezerv, Sofia.

Dimitrova,D.(2004). Соматотипологични особености на подрастващи на възраст от 7 до 17 години, Cпорт и наука, брой 3, София. // Somatotipologichni osobenosti na podrastvashti na vuzrast ot 7 do 17 godini, Sport I nauka, vol. 3, Sofia

Domuschieva, G. (2001). Aprobatsia na testa za orientacia kum zadachata I kum sebe si (TEOSQ) v bulgarski uslovia, Lichnost, motivacia, sport, Vol.9, NSA, Sofia. // Апробация на теста за ориентация към задачата и към себе си (TEOSQ) в български условия, Личност, мотивачия, спорт. т.9. НСА. София.

FIBA, (2000) Basketball for young players. Dykinson

Gigova, V., (2002). Statisticheska obrabotka I analizi na danni, Sofia, NSA - IPB //Статистическа обработка и анализ на данни. София: НСА - ИПБ.

Giosheva, K., K. Tzarov, R. Tzarova, (1990). Sistema za control, ocenka I optimizirane na sportnata podgotovka na momicheta I momcheta - 13-15 godini. Sofia, ECNPKFKS - IPB, p. 122-128 // Система за контрол, оценка и оптимизиране на спортната подготовка на момичета и момчета - 1315 години. София, ЕЦНПКФКС - ИПБ. стр.122-128.

Karalejič M., Jakovljevič S. (2001), Fundamentals of Basketball., Beograd, Fakultet sporta i fizičkog vaspitanja Beograd, Viša škola za sportske trenera Beograd, p.80-93.

Karalejič M., Jakovljevič S. (2007). Faktorska struktura košarkaških vestina, Zbornik radova sa medunarodnog skupa „Analitika I dijagnostika fizičke aktivnosti”, Beograd, Fakultet sporta i fizičkog vaspitanja, p.117125.

Tzarov, Kr. (2001), Faktori na sastezatelnata efektivnost na elitni otbori po basketball. Avtoreferat na dissert. Trud, NSA Press, p. 16-18 // Фактори на състезателната ефективност на елитни отбори по баскетбол Автореф. на дис. Труд. НСА. София.стр. 16-18

Tzarov, Kr., (2008) Podborat v baskeballa, Sofia, NSA Press, p. 56-72 // Подборът в баскетбола, София, НСА Прес.стр. 56-72.

Tzarov, Kr., (2012), Sastezatelnata efektivnost $\mathrm{v}$ basketballa, Sofia, Bolid ins, p. 120-131//Състезателната ефективност в баскетбола,София: Болид инс.стр.120-131.

Tzarov, K., V. Djordjevic (1997). Basketball - treniorsko rakovodstvo, Sofia, NSA IPB. // Баскетбол - треньорско рьководство. 
София: НСА-ИПБ.

Tzarov, Kr, R. Tzarova (2007) Testova bateria za nachalen podbor $\mathrm{v}$ basketballa, BFB, Sofia //Тестова батерия за начален подбор в баскетбола, БФБ, София.

Tzarova, R., (1981) Vazrastovi osobenosti $\mathrm{v}$ razvitieto na specifichnata rabotosposobnost pri podrastvashti basketbolisti. Dissert. VIF, Sofia.//Възрастови особености в развитието на специфичната работоспособност при подрастващи баскетболисти. Дис. труд, ВИФ.София.

Tzarova, R., (2013), Problemi na kontrola v basketballa // Проблеми на контрола в баскетбола, София. Болид инс. стр. 83-86

Tzarova, R., Borukova,M. (2012), Izsledvane vurhu nivoto na podgotvenost na uchenicite, kandidatstvashti v sportnite uchilishta $\mathrm{v}$ profilbasketball. Sport Inauka, 2011/2,p.89-97
//Изследване върху нивото на подготвеност на учениците, кандидатстващи в спортните училища с профил баскетбол, Спорm u наука, С., 2011/2, стр. 89-97

Wilkes, G., (1968), Palno rakovodstvo za treniora po basketball, Sofia, Medicina I fizkultura, p. 9-15 // Пълно ръководство за треньора по баскетбол, София, Медицина и физкултура, р.9-15.

Iancheva T. (2009). Psihologicheski izmerenia na sportnia talent, Lichnost, motivacia, sport. Vol 14, NSA Press, Sofia. // Психолигически измерения на спортния талант, Личност, мотивация, спорт. Том14. НСА. Прес. София.

Young, G., Moser, H, (1934). A short battery of tests to measure playing ability in women's basketball, Research Quarterly 5.

\section{Correspondence:}

Mariana Borukova

National Sports Academy "Vassil Levski" Department "Basketball, volleyball, handball" Studentski grad, 21, Acad. Stefan Mladenov Str.

Sofia 1700, Bulgaria E-mail: marianaborukova@gmail.com 